\title{
A case study: Enhancing execution of a nursing practice using organizational development principles
}

\author{
Vinitia E. Mathews, Barbara L. Olson \\ Patient Experience \& Patient Safety, LifePoint Health, United States
}

Received: February 28, 2017

Accepted: April 6, 2017

Online Published: April 12, 2017

DOI: $10.5430 /$ jha.v6n3p9

URL: https://doi.org/10.5430/jha.v6n3p9

\begin{abstract}
In 2013, a large health system endorsed bedside shift report as a nursing practice to increase patient engagement. While numerous hospitals in the system adopted the practice of bedside shift report, the system did not see anticipated improvements in patient safety or patient satisfaction. Observations across the system revealed tremendous variation in bedside shift report practice norms. The hypothesis was that bedside shift report was either (1) too different from entrenched hand-over processes to be effectively executed, or (2) the desired state of hand-over at the bedside had not been sufficiently articulated. The health system adopted a change management approach to tackle the issue, drawing from organizational development and organizational psychology literature. The result was the creation of a bedside shift report developmental framework which broke down the practice into a series of small, specific component parts, and demonstrated that it was normal to gradually evolve to the ideal, and only after basic behaviors became hardwired. The framework was revised once before arriving at the current iteration in use today. Patient safety and patient satisfaction data will be collected throughout 2017. In the meanwhile, ongoing observations show anecdotal evidence of specific safety catches as well as appreciations from nurses, patients and family members who have greatly benefitted from bedside shift report. The framework has also significantly increased nursing adoption and expertise with bedside shift report. The practice is now in place in 98\% of the health system's hospitals (compared to 52\% in 2013), with many units at mastery level.
\end{abstract}

Key Words: Bedside shift report, Patient safety, Patient satisfaction, Change management, Organizational development, Organizational psychology

\section{INTRODUCTION}

Bedside shift report is a practice norm where two nurses review key elements of a patient's hospital-based care and formally hand-over care in the patient's room, rather than at the nursing station. In 2013, nursing leaders in a large health system endorsed bedside shift report as a standard practice within the 70 hospital system, as an effort to increase patient safety and patient satisfaction. Although the organization provided structured coaching and resources to implement bedside shift report, the organization failed to see benefits typically associated with this practice.

\section{BACKGROUND}

\subsection{The situation within the health system}

Ever since the landmark Institute of Medicine (IOM) report ${ }^{[1]}$ patient-centered care has been a goal within healthcare. Since that time, the definition of patient-centered care has been expanded to include the family, and we now refer to such care as patient- and family-centered care (PFCC). The Institute for $\mathrm{PFCC}^{[2]}$ has four core concepts that guide how

\footnotetext{
*Correspondence: Vinitia E. Mathews; Email: Vinitia.Mathews@1pnt.net; Address: Patient Experience \& Patient Safety, LifePoint Health, 330 Seven Springs Way, Brentwood, TN 37027, United States. 
to achieve PFCC: dignity and respect, information sharing, participation and collaboration. PFCC recognizes collaboration with the patient and family as members of the healthcare team will improve quality of outcomes as well as efficiencies of care ${ }^{[3]}$ primarily because patients, and their families, are an invaluable source of information. ${ }^{[4]}$

The health system in this case has hospitals in more than 70 non-urban communities across the nation. In late 2012 , the health system made a commitment to enhance PFCC, as a means to improve patient safety and quality within the system. Using resources from such sources as the Institute for PFCC (IPFCC), the Agency for Healthcare Research and Quality (AHRQ) and the Institute for Healthcare Improvement (IHI), system leaders developed a strategic plan to involve patients (and their families) in their own care in three ways within the system: at the point of care (using bedside shift report), in process improvement efforts around quality and safety, and in governance (through the creation of a system Patient and Family Advisory Board [PFAB], as well as local patient and family advisory councils).

While the focus of this case study is on bedside shift report, the system patient and family engagement strategic plan does provide the recommended planning, shared understanding and organizational commitment that are necessary precursors to PFCC. ${ }^{[5,6]}$ The system created readiness to move towards patient-and family-centered care using several means: sending strong signals about the importance of this work (half of the system executive leaders are members of the system PFAB, and PFAB patient advisors are invited to speak to hospital administrators during company events); providing structured resources to guide patient engagement practices locally; and flexibility for hospital administrators to choose when and how (within endorsed parameters) to increase patient and family engagement within their own facility.

Bedside shift report was endorsed by the system because it is a proven practice to increase patient safety ${ }^{[7,8]}$ and patient experience. ${ }^{[9,10]}$ The practice has also been proven to positively increase nurse satisfaction, ${ }^{[10,11]}$ and the interpersonal relationship among nurses. ${ }^{[7,12]}$ Hospitals were encouraged to enroll in system-sponsored collaborative learning sessions about bedside shift report. These sessions provided nursing leaders and frontline nurses access to published literature, sample clinical report templates and coaching with a nursing subject matter expert. At the same time, members of the health system's patient safety and patient experience teams began observing bedside shift report, to validate the practice and provide real-time recognition and coaching.

Waiting an 18-month period to assess the impact of bedside shift report on outcomes, in the summer of 2014 , health sys- tem leaders analyzed patient safety and patient experience data in hospitals where bedside shift report had been introduced. Results did not reveal anticipated marked changes. Debriefings with system patient safety and patient experience team members revealed tremendous variation in bedside shift report practice norms. There was variation in the communication content between nurses, location where report took place (in patient room vs. in hallway), and degree to which safety checks were completed during report (for example tubing and line reconciliation, examination of dressings and assessment of environmental threats). Despite these variations, polled nurses almost universally believed they were practicing exemplary bedside shift report. The hypothesis was that bedside shift report was either (1) too different from entrenched hand-over processes to be effectively executed, or (2) the desired state of hand-over at the bedside had not been sufficiently articulated.

\subsection{Theoretical review}

The issue this health system faced relates to an implementation of change. Nurses were being asked to change several norms in order to conduct effective bedside shift reports. First, hand-over would have to occur in the patient's room rather than at the nursing station, potentially removing nurses from easy access to patient data, job aids, and social support. Second, patients and family members would be able to hear and potentially participate in the report process, something which made many nurses uncomfortable citing such reasons as patient privacy and fear of not being able to answer patient questions. Nurses in this health system were normal in having such feelings - there is abundant literature documenting nurses' reservations with bedside shift report. ${ }^{[10,13]}$

The nursing literature contains studies showing the benefits of bedside shift report for both nurses and patients, serving as a "call to action" for bedside shift report as a practice norm. ${ }^{[7-12]}$ However, a step-wise approach to managing the change at the scale we needed did not exist. Working with the hypothesis that bedside report was too different from existing practice to be fully embraced, we turned to the organizational development and organizational psychology literature for strategies that would support large scale change.

When dealing with any change, the more we can "shrink the change", ${ }^{[14]}$ or can break it down into "tiny habits $\AA$,", ${ }^{[15]}$ the more attainable that change will feel. We recognized that the change to hand-over at the bedside was complex, and the process needed to be broken into a series of small, specific component parts. We had to demonstrate to nurses that it was normal to gradually evolve to the ideal, and only after basic behaviors became hardwired. Working to that end, patient safety and patient experience leaders began scouring nursing 
literature for detailed information about specific observable skills and behaviors that constituted an effective hand-over at the bedside. Whilst abundant publications described unitspecific report templates, we could not identify literature that described the progression of actions and behaviors constituting an effective bedside shift report.

With the Plan-Do-Check-Act (PDCA) framework in mind, we set about defining bedside shift report across a developmental continuum, knowing the "check" step would help guide any needed revisions to the continuum. We additionally drew upon operant conditioning theory ${ }^{[16]}$ to manage the change. We recognized that in order to hardwire the practice over time, educating nurses about the granular steps encompassed during bedside shift report would be insufficient because training alone does not change behavior. If the practice was to be sustained over time, the process had to be capable of providing nurses with real-time positive recog- nition for exemplary bedside report, or real-time coaching about how to improve. In the next section we discuss how we used change management and PDCA concepts to achieve large-scale organizational change.

\section{Discussion}

Developed in September 2014, the health system's first generation bedside shift report developmental continuum framework had three levels of competency: basic, intermediate and mastery (see Figure 1). Basic level helped nurses over the first psychological hurdle: physically going into the room to give report. Even with this step, the health system wanted to recognize nurses for making efforts toward change, rather than "punishing" them for not achieving perfection. For this reason, the "basic" level expectation was that observed report be given in the room some, but not necessarily all, of the time.

\section{BASIC LEVEL}

- Report occurs at the bedside at least $75 \%$ of the time

- Outgoing nurse introduces oncoming nurse to patient

- Clinical report occurs outside the room (in a location with privacy)

OR

Occurs at the bedside

- Nurses ask what patient needs before leaving the room.

\section{INTERMEDIATE LEVEL}

- Report occurs at the bedside at least $90 \%$ of the time

- Outgoing nurse introduces oncoming nurse to patient

- Clinical report occurs outside the room (in a location with privacy) OR

\section{Occurs at the bedside}

- Nurses discuss patient main concerns with patient (pain, discharge, etc)

- Nurses ask what patient needs before leaving the room.
MASTERY LEVEL

- Report occurs at the bedside $100 \%$ of the time

- Clinical aspect of report occurs at the bedside. Patient is actively engaged in the report. No clinical jargon is used without explaining terms to patient.

- Outgoing nurse asks patient whether there is anything else the oncoming nurse needs to know.

- Nurses discuss patient main concerns with patient (pain, discharge, etc)

- Nurses ask what patient needs before leaving the room.

Figure 1. Bedside shift report stepped levels of mastery

Intermediate level status was achieved if observed nurses gave report in the room most of the time (90\%) and some safety checks (tubing and line reconciliation, examination of dressings and assessment of environmental threats) were completed by both nurses while in the room and there was verbal interaction with the patient. To achieve mastery level, 
report had to consistently take place in the patient room, the patient had to participate in report, and both nurses had to collaborate to complete safety checks. Our goal was to create a standardized practice of bedside shift report throughout the system.

While our health system is not a lean organization, ${ }^{[17]}$ our standardization efforts were informed by high reliability principles. ${ }^{[18]}$ The commitment to standardize came from a recognition that threats to effective communication (and thus patient safety) during shift report were consistent with those in other high consequence settings. The use of pre-flight safety checks in aviation and pre-procedure time-outs ${ }^{[18]}$ in healthcare, for example, are proven strategies for mitigating cognitive slips and variations in human performance that occur when familiar tasks are executed from memory. In addition, the system PFAB challenged us to standardize bedside shift report to the betterment of our patients across the nation.

We recognized that one potential risk of standardization comes from over-simplification, where failure to appreciate the complexity of a task could result in overly prescriptive directives with little value-add to end-users. ${ }^{[19]}$ The bedside shift report framework captures performance of coarse measures, such as whether report occurs inside or outside of a patient's room, helping clinicians reliably perform critical elements of bedside shift report. Equally important, however, the framework does not seek to prescribe granular elements of the clinical report, which is necessarily different according to patient population. Obstetrical patients, for example, benefit from a markedly different standard assessment than critically ill patients in the Intensive Care Unit.

For the next 15 months, the bedside shift report developmental framework was socialized across the 70-hospital system. The patient experience and patient safety teams conducted observations and provided coaching for nursing teams, as well as nursing leaders. What was shared during coaching included: published literature about bedside shift report; anecdotal stories about safety catches during report; anecdotal stories about bedside shift report taking less time than report given at the nursing station; and anecdotal stories about nurse satisfaction with the increased accountability that immediate patient needs had been met and the patient room was in good condition at the end of a shift. While the number of hospitals within the system using the practice of bedside shift report increased (from $52 \%$ in 2013 to $80 \%$ by the end of 2015), the patient experience and patient safety teams continued to observe a high degree of practice variation. We determined further refinement and additional specificity of the approach was needed.

Developed in December 2015, the second-generation bedside shift report framework is far more granular than the first version (see Table 1). While it still has three levels of competency (basic, intermediate and mastery), there are specific assessments relating to location of report, involvement of patient, setting of goals, use of a clinical template, and three distinct safety checks (tubing/lines, dressings and environmental threats). Using PDCA principles, before we could rollout the revised framework system wide, we needed a small test of change. We did so in two ways. First, the patient safety team selected pilot units on which to test the revised framework, seeking feedback from patients, frontline nurses and clinical leaders. Second, we sought feedback from the system PFAB. Feedback from these tests of change called for only minor tweaks to the framework, primarily to clarify language used in the framework. We made the minor adjustments and the revised framework was then ready for rollout.

Beginning in early 2016, the patient experience and patient safety teams began to actively socialize and vet the revised framework across the system. Baseline observations (minimum of 30 observations per month on at least one Med Surg unit in each facility) began to be collected in June of 2016. By the end of 2017, we expect to be able to correlate bedside shift report mastery with other safety and satisfaction indicators. Our hypothesis is that it will be possible to show dramatic differences in safety/experience outcomes, based on increasing levels of bedside shift report mastery. We intend to publish findings from this analysis after the data collection period is complete.

In the meanwhile, observation teams continue to hear anecdotal stories about specific safety catches ("near misses") from nurses as well as appreciations from patient and family members who have greatly benefitted from bedside shift report. The more granular second-generation framework has made it easier for nurses, and nursing leaders, to understand what is needed to move to mastery level, while also allowing enough variation to accommodate different patient populations. Additionally, having such granularity allows virtually any observer to recognize and coach in real time. Feedback from nursing leaders has been overwhelmingly positive and they have asked the patient safety and patient experience teams to utilize a similar approach to facilitate implementation of other practices. Bedside shift report is now in place in $98 \%$ of this health system's hospitals, with many units at mastery level. 
Table 1. Bedside shift report developmental framework

\begin{tabular}{|c|c|c|}
\hline Domain & Competency Level & Observed Behaviors \\
\hline \multirow{3}{*}{$\begin{array}{l}\text { Engagement: } \\
\text { I. Location }\end{array}$} & - Basic & $\begin{array}{l}\text { - Report occurs outside patient room. The report focuses on the needs of the staff. The reporting team } \\
\text { is physically separated from the patient. }\end{array}$ \\
\hline & - Intermediate & $\begin{array}{l}\text { - The report occurs inside the patient room. The location and body position of staff members is } \\
\text { selected to meet the needs of the staff and may purposefully shield the patient or family from } \\
\text { hearing information and engaging in the conversation. }\end{array}$ \\
\hline & - Mastery & $\begin{array}{l}\text { - Clinical report occurs at the bedside with the intention of having the patient and family close } \\
\text { enough that they may hear report and be heard if they interject. }\end{array}$ \\
\hline \multirow{3}{*}{$\begin{array}{l}\text { Engagement: } \\
\text { II. Patient } \\
\text { Involvement }\end{array}$} & - Basic & $\begin{array}{l}\text { - Patient not involved in report process. However, staff may greet the patient and engage in social } \\
\text { interactions primarily aimed at comfort. }\end{array}$ \\
\hline & - Intermediate & $\begin{array}{l}\text { - Report contains medical terms/jargon. But nurses make efforts to involve patient and clarify the } \\
\text { content so that key elements are comprehensible to the patient/family. }\end{array}$ \\
\hline & - Mastery & $\begin{array}{l}\text { - Patient is actively engaged in report. Language used during report is comprehensible to the } \\
\text { patient/family, considering the patient's assessed literacy level, cognitive status and learning needs. }\end{array}$ \\
\hline \multirow{3}{*}{$\begin{array}{l}\text { Engagement: } \\
\text { III. Goal Setting }\end{array}$} & - Basic & $\begin{array}{l}\text { - A communication/white board is present. However, a daily goal is not written or not updated during } \\
\text { hand-off. }\end{array}$ \\
\hline & - Intermediate & $\begin{array}{l}\text { - The daily goal(s) is updated during report. Daily goal may reflect medical priorities and use } \\
\text { language that is not understandable to the patient or family. }\end{array}$ \\
\hline & - Mastery & $\begin{array}{l}\text { - The daily goal(s) is updated during report. Daily goal(s) are written in words that are } \\
\text { understandable to and important to the patient. }\end{array}$ \\
\hline \multirow{2}{*}{$\begin{array}{l}\text { Safety: } \\
\text { I. Standardization }\end{array}$} & $\begin{array}{l}\text { - Basic } \\
\text { - Intermediate }\end{array}$ & $\begin{array}{l}\text { - Nurses conduct hand-off using individually-defined elements of performance/care. } \\
\text { - The unit has adopted a standard template that includes: clinical necessity \& \# of days each invasive } \\
\text { line/tube has been in place; fall risk \& fall prevention strategies in place; venous thrombus } \\
\text { embolism (VTE) risk \& prophylaxis plan. }\end{array}$ \\
\hline & - Mastery & $\begin{array}{l}\text { - Nurses use a standard, unit-defined template and include verbal report of the clinical necessity \& \# } \\
\text { of days each invasive line/tube has been in place; fall risk \& fall prevention strategies in place; VTE } \\
\text { risk \& prophylaxis plan. }\end{array}$ \\
\hline \multirow{2}{*}{$\begin{array}{l}\text { Safety: } \\
\text { II. Tubing \& Line } \\
\text { Reconciliation }\end{array}$} & $\begin{array}{l}\text { - Basic } \\
\text { - Intermediate }\end{array}$ & $\begin{array}{l}\text { - Visual inspection of infusates/tracing of invasive lines and tubes does not occur during hand-off. } \\
\text { - Visual inspection of infusates or tracing of lines and tubes is performed with two nurses at the } \\
\text { bedside. }\end{array}$ \\
\hline & - Mastery & $\begin{array}{l}\text { Two nurses at the bedside collaborate to: } \\
\text { 1) double check the accuracy of every infusate (label and rate) against the current MAR and } \\
\text { 2) verify the integrity/connection of each invasive line/tube (with the oncoming nurse tracing the } \\
\text { line/tube from the point of origin on the patient to the endpoint). }\end{array}$ \\
\hline \multirow{2}{*}{$\begin{array}{l}\text { Safety: } \\
\text { III. Dressings }\end{array}$} & $\begin{array}{l}\text { - Basic } \\
\text { - Intermediate }\end{array}$ & $\begin{array}{l}\text { - Visual inspection of dressings (including IV site) does not occur. } \\
\text { - Visual inspection of some dressings (e.g., IV site or abdominal dressing) is performed by the } \\
\text { oncoming nurse while both nurses are present. }\end{array}$ \\
\hline & - Mastery & $\begin{array}{l}\text { - Visual inspection of all dressings (including IV site) is performed by the oncoming nurse while both } \\
\text { nurses are present. }\end{array}$ \\
\hline \multirow[t]{2}{*}{$\begin{array}{l}\text { Safety: } \\
\text { IV. } \\
\text { Environmental }\end{array}$} & - Inter & $\begin{array}{l}\text { Environmental threats are present but not acted upon (e.g., the bed/chair alarm is not engaged for } \\
\text { patients with an assessed need; the pathway to the toilet is obstructed; other threats are readily } \\
\text { observed). } \\
\text { - Active scanning to detect and correct defects are observed or behaviors that anticipate needs and } \\
\text { reduce risk are observed (e.g., the nurse tells the patient/family when he/she will return; instructions } \\
\text { to call for assistance with toileting are given; specific information about how to reach the nurse for } \\
\text { an immediate need are provided). }\end{array}$ \\
\hline & - $\mathrm{Ma}$ & $\begin{array}{l}\text { - Active scanning to detect and correct threats occur and behaviors that anticipate needs and reduce } \\
\text { risk are observed. }\end{array}$ \\
\hline
\end{tabular}

\section{Conclusions}

This health system has made substantial gains with the execution of a nursing practice through the utilization of organizational development/organizational psychology principles. Other professionals may find value in this system's learnings:

- To make a change more attainable and palatable, shrink the change. ${ }^{[14,15]}$ The health system's creation of a performance continuum embeds the philosophy that evolution towards mastery is normal and expected. The expectation should not be that a practice will be mastered simply because it has been rolled out.

- "What looks like resistance is often a lack of clarity". ${ }^{[14]}$ For organizational initiatives that haven't fully been embraced, coaches should evaluate whether the procedural guidance is specific enough. The health system has found that being extremely specific and granular about staff expectations has deepened staff buy-in.

- Training alone will not change behavior. The health system has had great success using operant condition- 
ing principles ${ }^{[16]}$ to recognize and reward desirable behaviors, and coach to the expected norms. This health system is evolving the mastery of a nursing practice because it is not relying on training alone to change behavior.

\section{CONFLiCTS OF INTEREST Disclosure}

The authors declare they have no conflict of interest.

\section{REFERENCES}

[1] Institute of Medicine. Crossing the Quality Chasm: A New Health System for the 21st Century. Washington, DC: National Academy Press; 2001.

[2] Institute for Patient- and Family-Centered Care. Available from: www.ipfcc.org

[3] Moira S, Brown JB, Donner A, et al. The Impact of Patient-Centered Care on Outcomes. Journal of Family Practice. 2000; 49(9): 796-804.

[4] Taloney L, Flores G. Building Blocks for Successful Patient and Family Advisory Boards. Nursing Administration Quarterly. 2013; 37(3): 247-253. PMid: 23744471. https://doi.org/10.1097/ NAQ.0b013e318295ed58

[5] Ponte PR, Conlin G, Conway JB, et al. Making Patient-Centered Care Come Alive. Journal of Nursing Administration. 2003; 33(2): 82-90. PMid: 12584460. https://doi .org/10.1097/00005110 $-200302000-00004$

[6] Johnson B. Briefing Paper: Family-Centered Healthcare. Bethesda, MD: Institute for Family-Centered Care; 1997.

[7] Chaboyer W, McMurray A, Johnson J, et al. Bedside Handover: Quality Improvement Strategy To "Transform Care At The Bedside." Journal of Nursing Care Quality. 2009; 24(2): 136-142. PMid: 19287252. https://doi.org/10.1097/01.NCQ.0000347450.90676.d9

[8] Maxson PM, Derby KM, Wrobleski DM, et al. Bedside Nurse-ToNurse Handoff Promotes Patient Safety. MedSurg Nursing. 2012; 21(3): 140-144. PMid: 22866433.

[9] McMurray A, Chaboyer W, Wallis M, et al. Implementing Bedside Handover: Strategies For Change Management. Journal of Clinical Nursing. 2010; 19: 2580-2589. PMid: 20522156. https: //doi.org/10.1111/j.1365-2702.2009.03033.x
[10] Wakefield DS, Ragan R, Brandt J, et al. Making The Transition To Nursing Bedside Shift Reports. The Joint Commission Journal on Quality and Patient Safety. 2012 June; 38(6): 243-253. https://doi.org/10.1016/S1553-7250(12) 38031-8

[11] Reisenberg LA, Leisch J, Cunningham JM. Nursing Handoffs: A Systematic Review of The Literature. American Journal of Nursing. 2010; 110(4): 24-34. PMid: 20335686. https://doi.org/10.1 097/01.NAJ .0000370154.79857.09

[12] Anderson CD, Mangino RR. Nurse Shift Report: Who Says You Can't Talk In Front Of The Patient? Nursing Administration Quarterly. 2006; 30(2): 112-122. https://doi .org/10.1097/000062 16-200604000-00008

[13] Baker SJ, McGowan N. Bedside Shift Report Improves Patient Safety And Nurse Accountability. Evidence-Based Practice. 2010; 36(4): 355-358. https://doi.org/10.1016/j.jen.2010.03.009

[14] Heath C, Heath D. Switch: How To Change Things When Change Is Hard. Waterville, Me: Thorndike Press; 2010.

[15] Fogg BJ. Tiny Habits Method. 2011. Available from: www.tinyha bits.com

[16] Skinner BF. The Behavior of Organisms: An Experimental Analysis. New York: Appleton-Century; 1938.

[17] Womack JP, Jones DT, Roos D. The Machine That Changed the World: The Story of Lean Production. New York: Free Press; 1990.

[18] Haynes A, Weiser T, Berry W, et al. A Surgical Safety Checklist to Reduce Morbidity and Mortality in a Global Population. New England Journal of Medicine. 2009; 360: 491-499. PMid: 19144931. https://doi.org/10.1056/NEJMsa0810119

[19] Weick KE, Sutcliffe KM. Managing the Unexpected: Resilient Performance in an Age of Uncertainty. New York: John Wiley \& Sons; 2007. 